\title{
SOBRE LA OPACIDAD REFERENCIAL Y LA AMBIGÜEDAD DE DICTO/DE RE EN EL DERECHO*
}

\author{
Joaquín Rodríguez-Toubes Muñiz** \\ Universidad de Santiago de Compostela \\ joaquin.rodriguez-toubes@usc.es
}

\begin{abstract}
RESUMEN. Los contextos lingüísticos llamados opacos ocultan la referencia de los grupos nominales y pueden causar ambigüedad, que al manifestarse en las leyes adquiere relevancia jurídica. La opacidad referencial se comprueba en enunciados que cambian su valor de verdad cuando se sustituye un nombre por otro con la misma extensión. En tales situaciones la intensión cobra protagonismo, y por ello formular enunciados jurídicos en contextos opacos hace más visible e inteligible la atribución intensional característica del derecho. Por otra parte, la opacidad referencial suscita un tipo especial de ambigüedad, de raíz pragmática y estructura lógica, en la que un mismo grupo nominal admite una lectura inespecífica o de dicto (según lo dicho) y otra específica o de re (según la cosa). Varios ejemplos tomados del Código Penal español muestran la importancia de percibir esta ambigüedad.
\end{abstract}

Palabras clave: interpretación jurídica, opacidad referencial, ambigüedad.

\section{On Referential Opacity and De Dicto/De Re Ambiguity in the Law}

ABSTRACT. The so-called opaque linguistic contexts hide the reference of the nominal groups and can cause ambiguity, which becomes relevant for the law when it appears in legislation. The referential opacity occurs in statements that change their truth value when a name is substituted by another with the same extension. Intension takes prevalence in those situations, and therefore formulating legal statements in opaque contexts makes more visible and intelligible the intensional attribution peculiar to law. Besides, referential opacity raises a special type of ambiguity, with pragmatic roots and logical structure, in which a given nominal group admits an unspecific or de dicto reading (about what was said), and also a specific or de re reading (about the matter itself). Several examples taken from the Spanish Criminal Code show the importance of perceiving of this ambiguity.

Keywords: legal interpretation, referential opacity, ambiguity.

* Fecha de recepción: 22 de julio de 2016. Fecha de aceptación: 16 de febrero de 2017.

Este trabajo se integra en el proyecto de investigación DER2016-74898-C2-2-R financiado por el MINECO y FEDER. Una versión inicial, titulada «Contextos jurídicos opacos», fue presentada en el I Congreso de Filosofía Jurídica para el Mundo Latino, celebrado en Alicante del 26 al 28 de mayo de 2016.

:*: Profesor Titular de Filosofía del Derecho de la Universidad de Santiago de Compostela (Facultad de Derecho, 15782 Santiago de Compostela). 


\section{INTRODUCCIÓN}

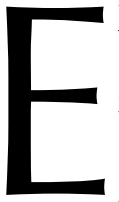

1 art. 248.1 del Código Penal español (CP) dice así: «Cometen estafa los que, con ánimo de lucro, utilizaren engaño bastante para producir error en otro, induciéndolo a realizar un acto de disposición en perjuicio propio o ajeno». ¿Quién es ese «otro» susceptible de engaño al que protege el artículo? En particular: ¿es una persona real o es una persona posible, una abstracción que pudiera no concretarse? ¿Comete ese delito quien teje un engaño lo bastante convincente para lograr que alguien le entregue dinero, aunque nadie haya caído en él? Comprobaremos que la respuesta doctrinal y jurisprudencial española es negativa (el engaño sin víctima se calificaría a lo sumo como tentativa de estafa), pero la letra del artículo admite ambas interpretaciones, porque es ambiguo en este punto. Esta ambigüedad se debe a que la palabra «otro» se usa tanto para referirse a una persona concreta («Pedro acusó a otro») como para hacer una referencia abstracta a alguien distinto del sujeto («Pedro fingió ser otro»). Pero es también una ambigüedad peculiar, que guarda relación con problemas de opacidad referencial que veremos discutidos por algunos filósofos y lingüistas, pero apenas por juristas. La explicación de la ambigüedad de la palabra «otro» en el art. 248.1 CP es atípica, porque es más lógica que etimológica. El doble sentido de «otro» en ese artículo se debe más a razones pragmáticas susceptibles de análisis lógico que a las causas semánticas que suelen estar tras las ambigüedades léxicas.

Tomemos otro ejemplo de oración ambigua: «Inés fue a Lugo a comprar una casa». Podemos entender que Inés fue a Lugo a comprar alguna casa (no se sabe todavía cuál) o cierta casa (ya se sabe cuál). La ambivalencia se comprueba fácilmente prolongando la frase: «Inés fue a Lugo a comprar una casa que le guste» (primera versión, que alude a una casa hipotética y requiere un subjuntivo); o «Inés fue a Lugo a comprar una casa que le gusta» (segunda versión, que alude a una casa real y pide un indicativo). Cabe dar cuenta de esta ambigüedad analizando los usos del artículo indeterminado «una»; pero es más informativa la explicación de los filósofos y lingüistas que distinguen entre una interpretación de dicto (sobre lo dicho) y otra de re (sobre la cosa). La oración «Inés fue a Lugo a comprar una casa» la interpretamos de dicto cuando entendemos que no se refiere a ninguna casa en particular; y en cambio la interpretamos de re cuando entendemos que se refiere a una casa específica. En oraciones así hay una oscuridad en la referencia que dificulta su comprensión, y de hecho es imposible saber el significado de este tipo de oraciones sin conocer el contexto pragmático en el que se formulan. Lo mismo ocurría con el art. 248.1 CP; y el doble sentido de «otro» en este artículo, con una acepción específica y otra inespecífica, lo capta bien la distinción lógico-lingüística entre lecturas de dicto y de re. Si se interpretan de re es porque se entiende referido a una realidad concreta: cierta persona física. En cambio, si se interpreta de dicto es porque se suspende el juicio sobre la referencia y esta es, a lo sumo, un ente abstracto o una mera hipótesis: una supuesta persona distinta del sujeto.

Esta situación de oscuridad referencial se da en diversas circunstancias lingüísticas, pero las más típicas son las expresiones de actitudes designadas con verbos como creer, querer y algunos otros. Por ejemplo, en oraciones como «Inés quiere comprar una casa en Lugo», la cual puede entenderse o bien de re, referida a una casa concreta, real y 
existente; o bien de dicto, referida a una casa abstracta, hipotética y acaso inexistente. $\mathrm{El} \mathrm{mismo} \mathrm{fenómeno} \mathrm{se} \mathrm{da} \mathrm{en} \mathrm{otros} \mathrm{contextos} \mathrm{prospectivos} \mathrm{(condicionales,} \mathrm{futuros...),} \mathrm{y,}$ por supuesto, tanto estos como los intencionales o proposicionales son muy frecuentes en el lenguaje del derecho, cuando regula acciones futuras intencionales. «Quien vaya a Lugo a comprar una casa podrá acceder al Registro municipal de viviendas», por ejemplo, sería una formulación legal típica y ambigua. Pues bien, aunque esta ambigüedad de dicto/de re tiene una importante presencia en el derecho, como tendremos ocasión de ver es excepcional que los juristas la reconozcan y más aún que la analicen y resuelvan en los términos lógicos y lingüísticos apropiados.

La oscuridad referencial creada por la ambigüedad de dicto/de re, muy presente en el lenguaje jurídico, guarda relación con la llamada «opacidad referencial» provocada por ciertas condiciones lingüísticas especiales que hacen prevalecer la intensión sobre la extensión, y que se manifiesta en enunciados donde no se da la sustitutibilidad salva veritate de términos correferentes. Las mismas condiciones que causan este fenómeno singular, que también puede reconocerse en el lenguaje jurídico, provocan la ambigüedad de dicto/de re, y de ahí que esta suela calificarse como un caso de opacidad referencial. Sin embargo, la opacidad referencial genuina oculta una única referencia, mientras que hay ambigüedad cuando la expresión admite más de una referencia, en este caso con un grado de especificidad distinto.

El primer apartado de este trabajo se dedica a atender al fenómeno de la opacidad referencial y de la formación de contextos opacos; y el segundo a la ambigüedad de dicto/de re en conexión con la ambigüedad inespecífico/específico.

\section{LA OPACIDAD REFERENCIAL}

Algunos lógicos —destacadamente Frege, Russell y Quine, a quienes acudiremos aquí- han identificado unas situaciones lingüísticas, conocidas como «contextos opacos», en las cuales al sustituir un nombre o un grupo nominal por otro con la misma referencia o denotación cambia el valor de verdad de la oración que lo contiene. Es decir, las oraciones opacas no conservan necesariamente su valor de verdad cuando en ellas se intercambian nombres que designan lo mismo (se aplican a lo mismo, tienen la misma extensión). En tales ocasiones los términos correferentes no cumplen una función puramente denotativa (designar algo), y por tanto no son plenamente intercambiables. Técnicamente se dice que estos contextos, como por ejemplo las informaciones sobre creencias, no cumplen el principio de sustitutividad, que QUINE (1961: 139) formula así: «Dado un enunciado de identidad verdadero, uno de sus dos términos puede ser sustituido por el otro en cualquier enunciado verdadero y el resultado será verdadero». Dicho de otro modo, en estos contextos los términos correferentes no son idénticos según el Principio de LEIBNIZ, pues solo lo son los que pueden intercambiarse salvaguardando el valor de verdad (Eadem sunt quorum unum in alterius locum substitui potest, salva veritate) ${ }^{1}$. QUINE (1961) pone este ejemplo:

${ }^{1}$ LeIBNIZ (ed. 1890: 219). Y sigue un ejemplo: «Ut Triangulum et Trilaterum». En palabras de RusselL (1905: 485): «Si $a$ es idéntico a $b$, lo que sea verdad de uno es verdad del otro, y uno de ellos puede ser sustituido por el otro en cualquier proposición sin alterar la verdad o falsedad de esa proposición». 
(1) Felipe cree que Tegucigalpa está en Nicaragua.

Aunque «Tegucigalpa» y «la capital de Honduras» tienen la misma referencia, no son expresiones sustituibles salva veritate, puesto que el enunciado (1) puede ser verdadero y no serlo este otro:

(2) Felipe cree que la capital de Honduras está en Nicaragua.

Lo que sucede aquí es que las expresiones «Tegucigalpa» y «la capital de Honduras» no se usan por su extensión (la ciudad de Tegucigalpa), sino por su intensión. Por eso estas situaciones se llaman también «contextos intensionales» y se dice que no son «transparentes» (no dejan ver la extensión) y que hay «opacidad referencial» ${ }^{2}$. Como recuerda QUINE, ya FREGE había hablado de estos contextos llamándolos «oblicuos» o «indirectos» (ungerade). Según FREGE (1892-2005: 31), normalmente se usan las palabras para hablar de su referencia, pero cuando se citan las palabras de otro indirectamente, en estilo indirecto, entonces la referencia del enunciado subordinado es un pensamiento o un sentido. Por ejemplo, cuando alguien habla del «lucero matutino» y reportamos sus palabras en estilo indirecto - «Dijo que veía el lucero matutino»—, la referencia de «lucero matutino» es el sentido que le dio el hablante, y no la que le damos nosotros. Por eso «Dijo que veía el lucero matutino» y «Dijo que veía Venus» no tienen necesariamente el mismo valor de verdad, aunque el «lucero matutino» es Venus.

Las condiciones que causan opacidad referencial son, destacadamente, las menciones o citas indirectas, las modalidades y las disposiciones o actitudes proposicionales.

\subsection{Citas}

La opacidad referencial de los contextos «indirectos» $\mathrm{u}$ «oblicuos» se puede explicar en algunos casos con la distinción entre uso y mención. Al formular oraciones acerca de nombres, ya sea en estilo directo o indirecto, seguimos reglas distintas que al usar esos mismos nombres. Como señaló Russell (1905: 486), «cuando se da $C$ estamos hablando de la denotación, pero cuando se da "C" se trata del significado». Supongamos que preguntamos a alguien cuándo llega y nos contesta: «El día 3». Si más tarde nos preguntan a nosotros cuándo llega podemos contestar con nuestras propias palabras («El día 3») o mencionando las suyas, ya sea en estilo directo («Sus palabras fueron: "El día 3"») o indirecto («Según sus palabras, el día 3»). Pues bien, el significado de «día 3» en estas respuestas no es necesariamente el mismo. La expresión cuando es usada tiene la referencia que nosotros le damos; y cuando es mencionada en una cita tiene la referencia que le dio el hablante citado. Y si la oración es ambigua

2 Explica QuiNE (1961: 139): «El principio de sustitutividad no debe extenderse a contextos en los que el nombre que va a ser sustituido aparece sin referir simplemente al objeto. Que falle la sustitutividad revela tan solo que el término a sustituir no es puramente referencial». A estos contextos los llamó QuINE (1961: 142; 1960: 144) «referencialmente opacos» por contraste con el término «transparente» usado por WHITEHEAD y RuSSELL (1927: 665), para quienes las proposiciones afirmadas («Sócrates es griego»), a diferencia de las mencionadas («Es verdad que Sócrates es griego»), son transparentes porque se dice algo a través de ellas, pero no acerca de ellas. Para adentrarse en la compleja temática de la opacidad referencial, véase en español la detallada introducción de GARCÍA SUÁREZ (1997: 251-312). 
(por ejemplo: «Me dijo que el día 3»), la expresión puede tener una u otra referencia según se interprete que se está usando o mencionando. Veamos esto con unos ejemplos jurídicos, basado en la Constitución Española (CE). El objetivo de este análisis será, en último término, comprender mejor el lenguaje del derecho y el derecho mismo.

\subsubsection{Estilo directo}

En primer lugar, comprobamos que en los contextos de estilo directo (citas literales) la sustitución de términos correferentes altera el valor de verdad.

(3) El artículo 12 CE dice: «Los españoles son mayores de edad a los 18 años».

(4) El artículo 12 CE dice: «Los españoles son mayores de edad a los 216 meses».

La oración (3) hace una cita correcta del artículo, y es verdadera. En la oración (4) se ha alterado la cita del artículo sustituyendo la expresión nominal «18 años» por otra con idéntica referencia («216 meses»), y el resultado es que la oración es falsa. Esto no es ninguna sorpresa, desde luego. Aunque 18 años son 216 meses, nadie pensará que «18 años» y «216 meses» son intercambiables en una cita literal. Y cualquier jurista sabe que hay que poner mucho cuidado al citar las leyes, porque en ellas no son lo mismo unas palabras que otras. Por eso no es fácil imaginar problemas jurídicos causados por la insustitutibilidad de los términos correferentes en el contexto de citas directas ${ }^{3}$.

\subsubsection{Estilo indirecto}

Cuando pasamos al estilo indirecto la cuestión se hace más compleja. Veamos estas dos oraciones:

(5) El artículo 12 CE dice que los españoles son mayores de edad a los 18 años.

(6) El artículo $12 \mathrm{CE}$ dice que los españoles son mayores de edad a los 216 meses.

El enunciado (5) describe fielmente el contenido del art. $12 \mathrm{CE}$ y podemos considerarlo verdadero. En cambio, es dudoso que el enunciado (6) sea igualmente verdadero, a pesar de que tiene el mismo contenido referencial. Ambos enunciados denotan lo mismo, pero no connotan lo mismo; y como consecuencia su valor de verdad podría ser distinto: (5) es verdadero, pero (6) puede serlo o no. El enunciado (6) es verdadero si usa la expresión «216 meses» por su extensión (18 años) y en el art. 12 CE la frase «18 años» se usa también por su extensión (18 años). En otro caso, la oración (6) es falsa, ya sea porque la cita que hace no es fidedigna o ya sea porque usa los términos tergiversando su significado. En virtud de esta ambigüedad, la oración (6) es un ejemplo de opacidad referencial en el derecho, y a su vez (por ello) una demostración de la

${ }^{3}$ Un ejemplo de dificultad (poco importante) podría ser cómo citar correctamente el art. 20.Uno.8. ${ }^{\circ}$ ) de la Ley 37/1992, de 28 de diciembre, del Impuesto sobre el Valor Añadido, según el cual están exentas de IVA las prestaciones efectuadas por entidades de Derecho público o de carácter social en servicios de «Educación especial y asistencia a personas con minusvalía». La dificultad viene por la disposición adicional $8 .{ }^{a}$ de la Ley 39/2006, de 14 de diciembre, de Promoción de la Autonomía Personal y Atención a las personas en situación de dependencia: «Las referencias que en los textos normativos se efectúan a "minusválidos" y a "personas con minusvalía”, se entenderán realizadas a "personas con discapacidad”. Así las cosas, ¿ cuál es la cita correcta del art. 20.Uno.8. ${ }^{\circ}$ c) de la Ley 37/1992: "minusvalía" o "discapacidad"?». 
fuerza de la intensión jurídica. Es dudoso si «18 años» aparece o no referencialmente en el art. 12 CE. Seguramente no, y por eso «18 años» y «216 meses» no son intercambiables. Si esto es así, la razón es que «18 años» en el art. 12 CE no solo denota una cantidad de tiempo, sino que tiene además una connotación y unas implicaciones peculiares que la distinguen de « 216 meses», aunque refieran lo mismo.

La opacidad referencial de los contextos indirectos crea incertidumbre en el derecho, porque una oración como (6) puede ser verdadera. Al contrario de lo que ocurría en las citas textuales en estilo directo, las afirmaciones indirectas sobre el contenido de las disposiciones jurídicas no necesitan ser fieles a la literalidad del texto para ser verdaderas. Esto es muy importante subrayarlo, porque es el sobreentendido habitual de los enunciados jurídicos, concebidos (en sentido kelseniano) ya como descripciones doctrinales de las normas válidas de un ordenamiento, o ya como pronunciamientos jurisprudenciales que dicen el derecho ${ }^{4}$. En algunos casos, incluso, la literalidad estorba. Por ejemplo, el art. 49 CE comienza así: «Los poderes públicos realizarán una política de previsión, tratamiento, rehabilitación e integración de los disminuidos físicos, sensoriales y psíquicos». Considérense ahora estos enunciados jurídicos sobre el art. 49 CE:

(7) El artículo 49 CE dice que los poderes públicos realizarán una política de integración de los disminuidos psíquicos.

(8) El artículo 49 CE dice que los poderes públicos realizarán una política de integración de las personas con discapacidad psíquica.

Ningún jurista dudará que si (7) es verdadera también (8) lo es, a pesar de que (7) es fiel a la letra del art. 49 CE y (8) no. Es más, probablemente hoy se prefiere (8) a (7) para describir el derecho en ese punto. En esta ocasión intercambiar términos correferentes («disminuidos» y «discapacitados») en un contexto indirecto no cambia el valor de verdad del enunciado. A pesar de la relevancia de los textos legales y de la importancia de ser fieles a sus palabras exactas, hay en el derecho muchas ocasiones como la citada, donde es viable la sustitución de términos por sinónimos correferentes sin alterar la verdad del enunciado. Que esto suceda puede deberse a dos causas. Una es que ambos términos tengan en el enunciado una función puramente extensional: se limitan a denotar algo (lo mismo en ambos casos). Otra es que ambos tengan la misma intensión relevante, además de la misma extensión. Como veremos, lo más probable es esto último, porque los contextos jurídicos típicos son intensionales y en ellos la descripción extensional no lo es todo.

La diferente intensión de los términos correferentes es lo que explica que estos no sean totalmente intercambiables en los contextos opacos indirectos u oblicuos. Este fenómeno interesa en el derecho porque pone de manifiesto contenidos de la intensión

4 Explica KELSEN (1960-1991): «La norma estatuida por el legislador [...], y el enunciado formulado por la ciencia del derecho describiendo esa norma [...] tienen características lógicas diferentes. De ahí que sea conveniente distinguir, aun terminológicamente, como "norma jurídica” y "enunciado jurídico", ambas expresiones» (p. 87). Si el enunciado jurídico doctrinal describe normas, el jurisdiccional también las avala: «La función del tribunal no es mero descubrimiento y formulación del derecho, y en este sentido, declaratoria [...]. El tribunal [...] debe decidir la cuestión de si la norma que aplicará fue producida constitucionalmente [...]. Esta formulación del enunciado jurídico dilucida la posición que el denominado derecho constitucional —es decir, las normas que regulan la producción de normas generales - tiene en el marco de un orden jurídico» (pp. 246-247). 
jurídica difíciles de diseccionar. ¿Cuál es la intensión peculiar que aporta el derecho a las expresiones que usa, y por la cual no son sustituibles por otras expresiones correferentes salva veritate? A mi juicio, en la intensión jurídica que se pone de manifiesto al comprobar la opacidad referencial del derecho destacan dos contenidos. Hablaré al respecto de dos modos de intensión jurídica, o simplemente de dos intensiones jurídicas. Ambas son previsibles y nada sorprendentes, pero es interesante (e infrecuente) observarlas en acción desprovistas de velos. Estos modos o aspectos de la intensión jurídica son, en primer lugar, la eficacia de la comunicación, que requiere sencillez y precisión en el lenguaje que hace públicas las normas; y en segundo lugar la generalidad, que demanda un lenguaje abstracto y de perfiles borrosos. Como se aprecia, ambas intensiones pueden empujar en sentidos opuestos y ser contradictorias, pero ambas conviven en el derecho.

Para empezar, ¿qué intensión peculiar tiene «18 años» frente a «216 meses», la cual hace que (5) y (6) sean diferentes? Probablemente la voluntad de eficacia del derecho, que recomienda claridad y sencillez en las formulaciones normativas; hasta el punto de que respetar mínimamente estas y otras propiedades asociadas, como la publicidad, puede llegar a ser un requisito de juridicidad. No se justifica nombrar la edad con «216 meses» si «18 años» es más sencillo y más claro. Ambas expresiones denotan lo mismo, pero solo la segunda connota el propósito comunicativo característico del lenguaje coloquial que emplean los destinatarios de la disposición. En cualquier caso, la opción no es trivial: una vez usada en el derecho, la expresión «18 años» genera implicaciones distintas a las de sus alternativas. Por ejemplo, nos invita a pensar las edades en años y no en meses, de manera que si algún día hubiese que pensar en un principio jurídico relativo a la edad (como - digamos - la edad en que un menor puede decidir sobre los tratamientos médicos que le conciernen o sobre sus derechos de imagen), debería plantearse en años y no en meses. Precisamente, la relevancia de la intensión jurídica estriba, sobre todo, en sus implicaciones normativas.

Ahora bien, la comunicación y la sencillez del mensaje no lo son todo en el lenguaje jurídico, como podremos ver en el siguiente ejemplo, también tomado de la CE:

Disposición Transitoria Segunda: «Los territorios que en el pasado hubiesen plebiscitado afirmativamente proyectos de Estatuto de autonomía y cuenten, al tiempo de promulgarse esta Constitución, con regímenes provisionales de autonomía, podrán [ampliar sus competencias autonómicas sin esperar cuatro años]».

Como se sabe y se sabía, estos territorios eran únicamente Cataluña, Galicia y el País Vasco. Considérense ahora estos enunciados jurídicos:

(9) La disposición dice que los territorios que en el pasado bubiesen plebiscitado afirmativamente proyectos de Estatuto de autonomía y cuenten, al tiempo de promulgarse la Constitución, con regimenes provisionales de autonomía, pueden...

(10) La disposición dice que Cataluña, Galicia y el País Vasco pueden...

En este ejemplo hemos sustituido una larga expresión de (9) por otra expresión correferente más precisa y el resultado (10) es una oración que ningún jurista consideraría equivalente a la primera. Porque el sentido de la descripción normativa en (9) no es solo designar unos territorios, sino sobre todo dar a entender por qué se designan. La disposición transitoria 2. ${ }^{a} \mathrm{CE}$ dice lo que afirma (9), pero no dice lo que afirma (10), aunque extensionalmente sea lo mismo. Lo que cambia entre (9) y (10) es la intensión. 
Pero, al contrario de lo que ocurría entre (6) y (7), ahora la diferencia no está en la mayor claridad y sencillez de la expresión jurídica (9), porque ocurre al revés; por tanto, la intensión jurídica ha de ser otra. De hecho estamos posiblemente ante la genuina intensión jurídica: la generalidad.

Nótese que si el enunciado de (10) parece falso, al contrario que (9), no es porque (10) se aparta del texto literal de la Constitución y como consecuencia el verbo «dice» es inapropiado. Tampoco (8) respetaba el texto literal del art. 49 CE y allí «dice» no parecía inapropiado. En realidad (10) seguirá pareciendo falso aunque cambiemos «dice» por un verbo que connote más el mensaje que su forma, por ejemplo «dispone», «comunica», «informa» o «transmite». Para hacer (10) verdadero tendríamos que neutralizar la intensión, por ejemplo sustituyendo «dice» por «viene a decir» (o incluso «significa», dando por sabido que a menudo el significado rebasa lo que se dice). El problema, por tanto, no es la fidelidad al texto. Si (10) parece falso es únicamente porque «Cataluña, Galicia y el País Vasco» carecen de la nota de generalidad que tiene «quienes...», y que es característica distintiva del derecho. Es esta intensión jurídica peculiar la que permite hacer implicaciones normativas y la que, en su caso, hará posible proyectar la disposición hacia el futuro ${ }^{5}$.

Reparar en la opacidad referencial nos desvela que cuando la disposición describe el supuesto de hecho regulado informa sobre su extensión, pero también aporta una intensión. Dicho de otro modo, la intensión es parte del mensaje del texto legal, y para tenerla en cuenta no es necesario recurrir a una finalidad o espíritu ajenos a su letra. Esto deberían tenerlo presente quienes critican las doctrinas interpretativas apegadas al texto reprochándoles, un tanto alegremente, que el significado literal de las disposiciones debe ceder ante su propósito o su justificación ${ }^{6}$. Lo cierto es que una interpretación del texto legal que verdaderamente haga honor al texto no ha de tener en cuenta solo su significado convencional estrictamente lingüistico, independiente del contexto de habla, sino también - y sobre todo- el significado efectivamente comunicado, en el cual participan activamente los componentes pragmáticos que aportan la intensión y las implicaciones del texto interpretado. Las cuales, por cierto, tienen mucho que ver con las intenciones, los fines y las razones justificativas que subyacen a dicho texto.

\subsection{Modalidades}

La opacidad referencial presente en los contextos indirectos de cita o mención se da también típicamente en los contextos modales, caracterizados por el uso de operadores como necesariamente o posiblemente; y esto repercute con fuerza en el derecho a

5 Tendría interés aprovechar el fenómeno de la opacidad referencial para investigar el enfrentamiento práctico entre las dos intensiones jurídicas identificadas - la generalizadora y la comunicativa -, y para discutir el peso respectivo que cada una de ellas tiene y debe tener en la legislación. Pero esto ha de quedar para otro trabajo.

${ }^{6}$ La tesis de la primacía del espíritu sobre la letra en la interpretación legal ha florecido en la jurisprudencia y en la doctrina españolas al amparo del art. 3.1 del CC. Ahora bien, el contenido y los efectos de esta tesis dependen de qué se entienda por letra o significado literal de las leyes, un concepto muy discutido, como se sabe. Véase un estudio en ITURRALDE (2014), quien defiende una acepción amplia como «significado convencional», el cual tiene en cuenta «los usos consolidados del lenguaje de los juristas» (p. 64). 
través de operadores deónticos como obligatorio o permitido. Los contextos opacos modales tienen su ilustración canónica en el siguiente ejemplo de QuiNE (1961: 143-144):

(11) El número de los planetas $=9$.

(12) 9 es necesariamente mayor que 7.

(13) El número de los planetas es necesariamente mayor que 7.

Aunque los enunciados (11) y (12) sean verdaderos ${ }^{7}$, no se sigue que lo sea (13). El ejemplo enseña que si en (12) sustituimos «9» por «el número de los planetas» cambia el valor de verdad de la oración, aunque ambas expresiones sean idénticas en su referencia. La explicación de QuINE es que «9» no es puramente referencial en el contexto modal ${ }^{8}$.

Este fenómeno se reproduce en el lenguaje normativo jurídico.

(14) El castellano = el idioma oficial de Colombia9.

(15) Conocer el castellano es obligatorio para todos los españoles ${ }^{10}$.

(16) Conocer el idioma oficial de Colombia es obligatorio para todos los españoles.

Está claro que (16) no se sigue de (14) y (15), como tampoco (13) se seguía de (11) y (12). La razón, de nuevo, es que «el castellano» en (15) no tiene una función puramente referencial. El operador modal «obligatorio» crea un contexto opaco en el que el significado extensional de «el castellano» no juega un papel determinante. Esta circunstancia se visibiliza al formalizar el enunciado (15), porque fuerza a situar la variable existencial fuera del operador deóntico «obligatorio» $(\mathbf{O})^{11}$.

(15') $\mathbf{O} \exists x(\mathrm{C} x)[\forall y(\mathrm{E} y) \rightarrow \mathrm{S} y x]$;

En lugar de:

$\left({ }^{* 15}\right) \quad \exists x(\mathrm{C} x) \mathbf{O}[\forall y(\mathrm{E} y)] \rightarrow \mathrm{S} y x$

Como veremos, esta misma diferencia en el alcance del operador o inductor modal es lo que explica la ambigüedad de dicto/de re.

\subsection{Actitudes}

La formación de contextos opacos es más notable todavía por efecto de verbos como «creer», «saber», «querer», «pretender» y varios otros, que expresan lo que se ha dado en llamar «actitudes proposicionales» ${ }^{12}$. El ejemplo clásico es aquí de RUSSELL (1905: 485):

7 El ejemplo es anterior a la devaluación de Plutón como planeta, por lo que asume (11) como verdad.

8 QUINE (1961: 144; 1960: 196).

9 «El castellano es el idioma oficial de Colombia» (art. 10 de la Constitución Política de Colombia).

10 «El castellano es la lengua española oficial del Estado. Todos los españoles tienen el deber de conocerla y el derecho a usarla» (art. 3.1 de la Constitución Española).

11 Tomemos que «C $»=\langle$ el castellano», «E» = «es español» $\mathrm{y}$ «S $\gg=\langle$ conocer». La fórmula adecuada (15') sería algo así: «Es obligatorio que dado un elemento $x$ que es el castellano, cualquier sujeto $y$ que es español ha de conocer $x$ ». La formulación alternativa errónea ( $\left.{ }^{*} 15^{`}\right)$ diría: «Dado un elemento $x$ que es el castellano, es obligatorio que cualquier sujeto $y$ que es español ha de conocer $x \gg$.

${ }_{12}$ Las actitudes proposicionales son estados mentales y disposiciones psicológicas acerca de algo afirmado en una proposición. RuSSELL acuñó la noción tomando como caso paradigmático creer, pero es común extenderla a disposiciones no epistémicas, como los deseos o las intenciones. Adoptó esta aplicación extensiva, aun- 
(16) Jorge IV quería saber si Scott era el autor de Waverley.

(17) Scott era el autor de Waverley.

(18) Jorge IV quería saber si Scott era Scott.

Según RuSSELL, la clave de la ambigüedad de la oración (16) está en que en ella la expresión «el autor de Waverley» puede aparecer de dos modos. En el primario, una y solo una persona escribió Waverley y Jorge IV quería saber si Scott era esa persona. En el secundario, Jorge IV quería saber si una y solo una persona escribió Waverley y Scott era esa persona. La distinción se puede hacer visible formalizando (16) con las dos interpretaciones alternativas; pero también, como pronto veremos, recurriendo a la distinción lingüística entre las modalidades de dicto (sobre lo dicho) y de re (sobre la cosa). Compárese (simbolizamos Waverley como «W» y Scott como «S»):

(16a) Jorge IV quería saber si $\exists x(\mathrm{~W} x \wedge \mathrm{S} x) \quad$ (modo secundario; lectura de dicto)

(16b) $\exists x(\mathrm{~W} x)$ y Jorge IV quería saber si $\mathrm{S} x$ (modo primario; lectura de re)

El ejemplo puede reproducirse sin dificultad para un entorno jurídico:

(19) El tribunal quería saber si Cataluña, Galicia y el País Vasco eran los territorios que en el pasado plebiscitaron afirmativamente proyectos de Estatuto de autonomia y contaban, al tiempo de promulgarse la Constitución, con regímenes provisionales de autonomía.

(20) Cataluña, Galicia y el País Vasco eran los territorios que en el pasado plebiscitaron afirmativamente proyectos de Estatuto de autonomia y contaban, al tiempo de promulgarse la Constitución, con regimenes provisionales de autonomía.

(21) El tribunal quería saber si Cataluña, Galicia y el País Vasco eran Cataluña, Galicia y el País Vasco.

De hecho, el modelo del ejemplo se reproduce constantemente al aplicar el derecho en los casos que cuentan con una única respuesta correcta. Tal vez no sean muchos, pero los hay. Pensemos, por ejemplo, que una disposición habla de «los ministros del Gobierno» y un juez debe identificar qué miembros forman esa clase.

(22) El juez quería saber si $\{a, b, \ldots n\}$ son la clase $\mathrm{C}$.

(23) La clase $\mathrm{C}=\{a, b, \ldots n\}$.

(24) El juez quería saber si $\{a, b, \ldots n\}$ son $\{a, b, \ldots n\}$.

¿Qué nos enseña esto? Nos enseña que las expresiones y descripciones con contenido referencial del lenguaje jurídico — como «los territorios que...»— no cumplen únicamente la función de identificar las realidades que refieren. A veces el derecho no es una norma superpuesta a una realidad (unos elementos $\{a, b, \ldots n\}$ que existen de hecho), sino una norma que construye una realidad (una clase $\mathrm{C}$ que existe como posibilidad). Esto es importante percibirlo cuando se interpretan las leyes. Para entender cabalmente las leyes hay que comprender qué papel desempeñan en ellas los términos referenciales, lo cual requiere procesar adecuadamente la información pragmática para dar la forma lógica correcta a los enunciados jurídicos. Ha de asumirse que en ciertos contextos opacos las descripciones legales no están ahí para referirse a algo, sino para hablar de algo. Por decirlo así, los entes o clases nombrados por las leyes no son meros objetos afectados por la prescripción y externos a ella, sino que son creaciones de la

que no es pacífica. Cfr. en LAMARQUE, ed. (1997) las entradas «Propositional Attitudes» (que incluye lamentar o desear) e «Intensionality» (que excluye buscar o desear). GARCíA SuÁREZ (1997: 278) hace un uso aún más amplio, que incluye decir y afirmar, y por tanto estudia los problemas referenciales causados por las citas en el contexto de las actitudes proposicionales. 
propia ley e internos a la prescripción. Esta se pone de manifiesto también en la distinción entre interpretaciones de dicto y de re, como veremos.

La opacidad referencial crea una ambigüedad pragmática en las expresiones nominales, por cuanto cabe dudar de si la intención de quien las usa - el legislador, digamos - es designar una realidad (uso extensional o referencial) o aludir a unas propiedades (uso intensional o atributivo). En el primer caso es indiferente cómo se nombre o describa la realidad si con ello queda identificada. En el segundo caso la denominación o descripción es lo que connota las diferencias intensionales, y por tanto es distintiva e insustituible. Como es la intensión, más que la extensión, lo que fundamenta la posibilidad de proyectar una descripción normativa a otros casos análogos, es decisivo comprender si un nombre o descripción legal tiene función referencial o atributiva. Y por eso la ambigüedad creada por los contextos opacos puede llegar a ser un problema jurídico.

Continuemos con otro famoso ejemplo de opacidad referencial propuesto por QUINE (1956). Supongamos que Ralph ve un hombre con sombrero marrón y cree que es un espía.

\section{(25) Ralph cree que el hombre del sombrero marrón es un espía.}

La expresión «el hombre con el sombrero marrón» tiene la ambigüedad pragmática que comentamos, porque no sabemos con certeza si tiene la función de referir la persona real que llevaba el sombrero (Orcutt, por seguir a QUINE) o de comunicar las características de la persona que el sujeto cree un espía, a saber: ser un hombre con sombrero marrón. Porque puede ocurrir, como dice QuINE, que Ralph vea en la playa a un hombre que cree de fiar, sin saber que es la misma persona (Ortcutt) que había visto con sombrero.

\section{(26) Ralph no cree que el hombre que vio en la playa sea un espia.}

La oraciones (25) y (26) son compatibles, pese a que designan la misma persona con mensajes contradictorios, porque estas oraciones no son acerca de esa persona (Orcutt), sino acerca de las hipotéticas personas descritas. Esta situación la provoca la construcción «cree que», la cual expresa una actitud proposicional y es «referencialmente opaca» (QUINE, 1956: 179). Como no podemos estar seguros de que «el hombre con sombrero marrón» en (25) tenga función referencial, no podemos saber cómo entender correctamente la oración. Esto se demuestra al intentar formalizar el enunciado, como enseña QuiNE.

(25a) Ralph cree que $(\exists x)$ ( $x$ es un espía).

(25b) $\quad(\exists x)$ (Ralph cree que $x$ es un espía).

La primera versión (25a) es la lectura de dicto (según lo dicho) de la misma oración (25): Ralph cree que hay alguien (un hombre con sombrero marrón) que es un espía. La segunda versión (25b) es la lectura de re (según la cosa) de la oración (25): hay alguien (un hombre con sombrero marrón) que Ralph cree que es un espía. Ambas lecturas son posibles, pero evidentemente no significan lo mismo. La segunda lectura (y formalización) no es posible en el caso relatado por QuINE. Ni tampoco en los casos de ambigüedad como:

(27) Ralph cree que alguien es un espía [Ralph believes that someone is a spy]. 
El derecho es un entorno fecundo para esta ambigüedad pragmática, porque se nutre de actitudes proposicionales. En realidad, todo el derecho puede reconstruirse como expresión de una actitud proposicional, y por tanto como contexto referencialmente opaco. Pensemos, por ejemplo, en el art. 5 CE ( «La capital del Estado es la villa de Madrid»):

\section{(28) El constituyente español quiso que la capital del Estado fuese la villa de Madrid.}

Esta oración (28) es referencialmente opaca, por cuanto cabría dudar si la expresión «la villa de Madrid» es extensional y se limita a designar la ciudad, de manera que es sustituible salva veritate por «Madrid» o por «la ciudad donde nació Carlos III»; o, por el contrario, aporta un significado adicional, una intensión, que no recogen otras fórmulas aparentemente sinónimas como esas.

Por lo demás, así como las normas jurídicas pueden reconstruirse como actitudes proposicionales del legislador, también puede reportase como citas en estilo indirecto:

(29) Según el derecho español, los españoles son mayores de edad a los 18 años.

Así las cosas, no sorprende que el derecho manifieste fenómenos causados por la opacidad referencial, como la ambigüedad de dicto/de re, de la que se ocupa el resto de este trabajo.

\section{LA AMBIGÜEDAD DE DICTO/DE RE}

ARISTÓTELES, en sus Refutaciones sofísticas ( $\$ 166 .{ }^{2} 20-30$ ), enumera lo que llama «composición» entre los argumentos con que se puede refutar a otro en función de su expresión. Son ejemplos de «composición» —escribe- «cosas tales como: es posible que el que está sentado camine y que uno que no escribe escriba» ${ }^{13}$. Los ejemplos de Aristóteles presentan varias capas de ambigüedad (necesidad/contingencia, potencia/ acto y otras); pero la que nos interesa aquí fue puesta de manifiesto en el siglo XII por Pedro ABELARDO, al notar que una oración como «Es posible que quien está de pie esté sentado» (possibile est stantem sedere) es susceptible de dos interpretaciones. Entendida per compositionem o de sensu (hoy se prefiere de dicto) afirma que es posible que alguien esté a la vez de pie y sentado, lo cual es falso. En cambio, entendida per divisionem o de re afirma que quien está de pie puede estar sentado en algún momento, lo cual puede ser verdadero ${ }^{14}$.

La posibilidad de interpretaciones de dicto y de re se explica por la diferente relación que se establece en cada una de ellas entre el nombre o la expresión nominal («quien está de pie») y el verbo o la estructura modal que crea la ambigüedad («es posible que»); y repercute en el grado de especificidad con que se entiende el propio nombre. La «estructura modal» causante de la ambigüedad se forma por circunstan-

13 La cita sigue así: «(pues no significa lo mismo que uno siga dividiendo o diga componiendo que es posible que el que está sentado camine; de la misma manera si uno establece por composición que el que no escribe escriba: pues significa que tiene capacidad de escribir mientras no escribe; en cambio, si no compone, significa que, cuando no escribe, tiene capacidad de escribir)» (ARISTÓTELES, ed. 1982, \$166. ${ }^{a} 20-30$ ).

14 Abelardo (ed. 1958: 13). Vid., al respecto, entre otros: KnEAle (1962: 624-625) y PINZANi (2003: 106 y ss.) 
cias diversas, pero entre ellas destacan las que ya vimos en el origen de los contextos intensionales: las menciones indirectas, las modalidades y las actitudes subjetivas o proposicionales. En la interpretación de dicto, el nombre se ve afectado o alcanzado por el verbo y forma parte de la estructura modal creada: es posible que alguien de pie esté sentado. El resultado es una versión inespecífica de «quien está de pie» (no es nadie en concreto) y una proposición falsa. En la interpretación de re, el nombre queda fuera del alcance del verbo y de la estructura modal: hay alguien de pie y es posible que esté sentado. El resultado es ahora una versión específica de «quien está de pie» (es una persona que está efectivamente de pie), y una proposición que puede ser verdadera.

La ambigüedad creada por la posibilidad de lecturas alternativas de dicto y de re se da en una gran cantidad de casos, también en el derecho. Estas situaciones tienen un claro aire de familia con los contextos opacos que hemos examinado en el apartado anterior, por cuanto en aquellas también hay oscuridad sobre la referencia. Además, las mismas condiciones que crean los contextos opacos crean también la ambigüedad de dicto/de re. Pero mientras que en la opacidad referencial genuina la incertidumbre se produce ante la posibilidad de términos con la misma extensión y distinta intensión, en cambio la ambigüedad de dicto/de re tiene lugar porque un mismo término puede tener al menos dos extensiones distintas, una más específica que la otra. Esta ambigüedad no se debe a la homonimia ni a la polisemia de las palabras, aunque puede manifestarse como ambigüedad léxica, sino a razones sintácticas y pragmáticas que solo pueden captarse con precisión con ayuda de la lógica ${ }^{15}$.

Como quedó apuntado, la ambigüedad de dicto/de re guarda estrecha relación con la ambigüedad inespecífico/específico, y no es fácil deslindarlas. La Nueva gramática de la lengua española (REAL ACADEMIA ESPAÑOLA, 2009, \$\$ 15.9 y 15.10) las trata conjuntamente y presenta a la primera ambigüedad como una variante de la segunda, provocada por un «inductor modal» externo al grupo nominal. Por su concisión y relevancia para nuestro tema, merecen cita estos fragmentos:

La ambigüedad que se da en los contextos de inducción modal entre la interpretación específica, denominada LECTURA DE RE en la tradición lógica, y la inespecífica, llamada generalmente LECTURA DE DICTO en esa misma tradición, tiende a vincularse al distinto ÁMBITO O ALCANCE que en cada caso tiene el inductor contenido en la oración con respecto al grupo nominal. Así, los dos enunciados siguientes contienen un inductor modal, el condicional [...]: Me gustaría ver una película; Hay una película que me gustaría ver. Como se puede comprobar, frente a las dos interpretaciones que admite una película en el primero (es decir «una película concreta de un género concreto», o bien «una película cualquiera»), en el segundo tan solo es posible la lectura específica («una película cualquiera») (\$15.10b, vol. I: 1140).

En general, la interpretación específica de un grupo nominal indefinido se obtiene cuando este no se ve afectado por la presencia del operador modal, de modo que se dice

15 Las referencias a la ambigüedad de dicto/de re abundan en los estudios de lógica y de filosofía de lenguaje, entre ellos varios de los ya citados, como KnEALE (1960), LAMARQue, ed. (1997: 316-319, passim) o GARCíA SuÁREZ (1997: 279). También la lingüística se ha ocupado de esta ambigüedad, así GuTIÉRREZ ORDÓÑEZ (1995). En cambio, la doctrina jurídica apenas la ha tratado, por lo que me consta. Entre las escasas excepciones: YAFFE (2011) y ANDERSON (2014). Pero estos autores tratan también como ambigüedad de dicto/ de re algunos problemas de indeterminación semántica sin causa lógico-sintáctica, tales como la ambigüedad específico/inespecífico de los nombres de cargos, como «el gobernador de California» (YAFFE, 2011: 194): vid. infra $\$ 2.2 .1$. 
que - en la lectura de re- el grupo nominal indefinido queda fuera de su ámbito. En la interpretación inespecífica o de dicto, la relación entre ambas unidades es la contraria: el operador toma dentro de su ámbito al grupo nominal, por lo que la referencia de este se ve condicionada o determinada por aquel ( $\$ 15.10$ c, vol. I: 1140).

Los entornos modales que inducen a la interpretación inespecífica de los grupos nominales indefinidos se denominan en la tradición lógica CONTEXTOS OPACOS O INTENSIONALES. Estos entornos, muy a menudo prospectivos, permiten dejar en suspenso la existencia del referente de alguno de los argumentos de la predicación. Focalizan, pues, su mera INTENSIÓN, es decir, su significado, por tanto las propiedades que caracterizan a los elementos que dicho argumento designa. Este fenómeno se conoce como OPACIDAD REFERENCIAL. Así, el complemento directo de la oración Busco un taxi que me lleve al aeropuerto no se refiere a ningún taxi en particular, e incluso podría ser que en el momento en que se emite el enunciado no hubiera vehículo alguno que pudiera satisfacer tal descripción. La interpretación semántica obtenida está, pues, inducida por la naturaleza prospectiva del verbo buscar [...] y también [...] por la presencia del subjuntivo, ya que la oración Busco un taxi que tiene un vidrio quebrado se referiría a un taxi en particular (\$15.10d, vol. I: 1140).

La Nueva gramática advierte también que «existen muchas diferencias entre los especialistas en cuanto a si la (in)especificidad es un fenómeno semántico o más bien pragmático» ( $\$ 15.9 \mathrm{~d}$, vol. I: 1135$)$. No es de extrañar, porque las situaciones que crean especificidad o inespecificidad son muy variadas. En cualquier caso, el resultado es una ambigüedad semántica cuya raíz es pragmática, porque tiene que ver con las intenciones del hablante y con el modo en que el oyente las capta dado el conocimiento del entorno que cada uno de ellos tiene y que en alguna medida comparten. Por otro lado, esta ambigüedad también es sintáctica, ya que tiene que ver con la estructura de las oraciones y con la función que en ella desempeñan sus componentes.

Observemos esta oración, inspirada en (27):

(30) Raúl cree que un vecino es un espía.

Aquí hay tres posibles lecturas (simbolizo «ser un vecino» como «v») ${ }^{16}$ :

$\left(30 a_{1}\right)$ Raúl cree que todo posible vecino es un espía, que quien sea vecino es un espía. Raúl cree que $(\forall v)$ ( $v$ es un espía). Lectura de dicto, inespecífica y universal.

$\left(30 a_{2}\right)$ Raúl cree que algún vecino suyo es un espía; sospecha que hay un vecino espía. Raúl cree que $(\exists v)$ ( $v$ es un espía). Lectura de dicto, inespecífica pero singular.

(30b) Raúl cree que cierto vecino suyo es un espía; hay un vecino de quien sospecha. $(\exists v)$ (Raúl cree que $v$ es un espía). Lectura de re, específica.

Todo indica que confluyen aquí factores léxicos, sintácticos y pragmáticos para crear la ambigüedad. Lo mismo ocurre en muchas oraciones del lenguaje jurídico. A continuación pondré algunos ejemplos tomados del Código Penal español (CP), cuya especial relevancia es innecesario subrayar. Mostraré primero un grupo de ejemplos donde es ambigua la construcción «un + grupo nominal»; y en segundo lugar ejemplos donde la ambigüedad de dicto/de re se solapa con otras modalidades de la ambigüedad específico/inespecífico, en las que ya se reconocen causas léxicas.

16 Descarto una cuarta lectura, según la cual Raúl cree que todos los vecinos que hay son espías [ $\forall v$ (Raúl cree que $v$ es un espía)], porque la oración (30) no la admite. Para expresar esa idea habría que decir algo así: Raúl cree que los vecinos son espías. Lo cual también podría leerse de dicto [Raúl cree que $\forall x$ ( $x$ es un espía)]. 


\subsection{Indefinición referencial}

\subsection{1. «Un preso»}

Art. 470.1 CP: «El particular que proporcionare la evasión a un condenado, preso o detenido, bien del lugar en que esté recluido, bien durante su conducción, será castigado con la pena de prisión de seis meses a un año y multa de doce a veinticuatro meses».

Del art. 470.1 CP podemos extraer el siguiente enunciado jurídico:

(31) Es delito proporcionar la evasión a un preso del lugar en que esté recluido.

Este enunciado es ambiguo, porque admite dos interpretaciones:

(31a) De dicto: proporcionar la evasión a un posible preso (hipotético).

(31b) De re: proporcionar la evasión a un preso concreto (real).

Con la primera interpretación sería delito abrir las puertas de una prisión o difundir sus claves de seguridad sin saber si hay o no presos dentro, sin que los haya o sin que, de haberlos, ninguno se evada. Con la segunda interpretación, para que haya delito ha de haber al menos un preso al que se presta ayuda; e incluso (aunque esto es asunto aparte) que consiga evadirse. La lectura de re es la que viene primero a la mente, sin duda incitada por «que esté recluido»: nos imaginamos una persona real presa a quien el autor del delito ayuda a fugarse. La jurisprudencia y la doctrina ni se plantean otra $\cos a^{17}$. Pero la lengua española, dada la estructura sintáctica del artículo, sí permite otra lectura alternativa. Recordemos el ejemplo de la Nueva gramática: «Busco un taxi que me lleve al aeropuerto» ${ }^{18}$.

17 Vid., entre la jurisprudencia, la SAP Castellón 67/2003, de 12 de marzo (FD 2..$^{\circ}$ : «La simple lectura del precepto pone de manifiesto que el tipo penal no menciona solo el proporcionar o favorecer la evasión, sino que exige también como requisito integrante del mismo que se favorezca la evasión del lugar donde se esté recluido o durante su conducción. [...] Esta y no otra es la interpretación literal que debe hacerse del artículo 470.1 del Código Penal en cuanto existe como requisito del tipo no solo que se proporcione la evasión a un condenado, preso o detenido, sino también que lo sea del lugar en que esté recluido o durante su conducción desde ese lugar». En la doctrina, por ejemplo, QUERALT (2015: 1293): «Se trata de un delito de favorecimiento del hecho de otro, aquí del privado de libertad; [...]. Se trata, en fin, de connivencia con el fugado». También García AlbERO (en QuiNTERO OLIVARES, 2011, II: 1428): «Se contempla en este precepto la conducta del tercero que proporciona la violación de una situación de guarda o custodia del condenado, preso o detenido». Esto es, del preso, no de un preso. Además GARCía AlBERO asume que el delito se comete únicamente si alguien de hecho se evade, pues consiste en realizar «actos sin los cuales la evasión no se hubiese realizado» (ibid., 1430). Si así fuera, quedaría excluida una interpretación de dicto extensible al supuesto de que ningún preso reciba efectivamente la acción del autor del delito. Sin embargo, el artículo nada dice acerca del resultado del acto (doloso) de proporcionar los medios para una evasión. La acción de una evasión que el agente cree probable basta para integrar el tipo, al menos cuando se interpreta de dicto, sin necesidad de que se evada preso alguno; e incluso sin que haya preso alguno susceptible de evadirse y sea imposible lo que el agente creía probable.

18 Adviértase que la diferencia entre las interpretaciones de dicto y de re del art. 470.1 CP no estriba propiamente en negar o afirmar que la evasión es una condición del delito. Por un lado, la lectura de re es compatible con entender que el delito es la actividad de proporcionar la evasión de un preso aunque no se produzca ese resultado. Cabría objetar que «proporcionar» una evasión no es simplemente facilitarla, sino que la ayuda ha de ser determinante para que la evasión se produzca, y esto solo puede comprobarse si se produce. Así parece entenderlo la mayoría de la doctrina. Sin embargo, «proporcionar» no es conseguir u obtener, sino «poner a disposición de alguien lo que necesita o le conviene» (dice el Diccionario de la Real Academia Española). En los términos del artículo, proporciona la evasión de un preso quien pone a disposición de este los medios para evadirse, y esta conducta es anterior a la eventual evasión e independiente de ella. Por otro lado, la lectura de dicto es compatible con entender que proporcionar la evasión de un preso es un delito de resultado. La clave de la lectura de dicto es que no hay ningún preso específico cuya evasión se proporciona. Esto sucede 
Una explicación verosímil de la predisposición de los juristas a la lectura de re, que es a menudo la única que se acepta, puede ser el efecto de heurísticos, prejuicios o sesgos cognitivos como la disponibilidad o la representatividad (vid. ANDERSON, 2014). Todos, incluidos jueces y demás juristas, al interpretar una situación o al resolver un problema tendemos a sobredimensionar los casos que nos vienen a la mente y los que nos parecen representativos, y a infravalorar otras posibilidades aunque estas sean más probables. Esto ha sido comprobado experimentalmente, con resultados a menudo sorprendentes ${ }^{19}$. Dada nuestra condición psicológica, es natural que en los planteamientos ambiguos, a falta de indicadores que sugieran lo contrario, prefiramos las interpretaciones asociadas a personas y situaciones reales que nos imaginamos fácilmente, en vez de las hipótesis y los supuestos imaginarios.

\subsection{2. «Un menor de edad»}

Considérese ahora el art. 188.1 CP y las posibles interpretaciones de un enunciado jurídico que describe parte de su contenido:

Art. 188.1 CP: «El que induzca, promueva, favorezca o facilite la prostitución de un menor de edad o una persona con discapacidad necesitada de especial protección, o se lucre con ello, o explote de algún otro modo a un menor o a una persona con discapacidad para estos fines, será castigado con las penas de prisión de dos a cinco años y multa de doce a veinticuatro meses».

(32) Es delito promover la prostitución de un menor de edad.

(32a) De dicto: promover que algún posible menor sea víctima de prostitución.

(32b) De re: promover que un menor concreto (real) sea víctima de prostitución.

En la lectura de dicto es delito alentar la prostitución infantil en publicaciones o películas aunque no las vea ningún menor. No así en la lectura de re, que exige que haya al menos un menor que sea víctima de la actuación delictiva. Nótese que la diferencia de interpretaciones no depende de si ha de haber o no un menor que efectivamente sufra prostitución. En ninguna de las dos lecturas se requiere (es un asunto aparte) que la actividad de promover la prostitución tenga el resultado que busca. La diferencia estriba en si ha de haber o no un menor que sea víctima de la actividad promocional, aunque esta no logre su propósito. En este punto, como cabría esperar, la tónica es la lectura de re ${ }^{20}$.

claramente cuando no hay ningún preso que se evade, pero puede suceder también cuando un preso se evade como consecuencia de la actuación de un «particular» que no sabe de su existencia. Por lo demás la exigencia de dolo tampoco es inconveniente para la lectura de dicto, porque bastaría con la voluntad de que se produzca la evasión de algún preso. Nada en el artículo exige que el agente quiera que se evada una persona específica. Ni siquiera hay que acudir a la noción de dolo eventual, entendido como la aceptación de un daño que no se buscaba, porque cabe exigir que el agente quiera la evasión que proporciona. La peculiaridad de la lectura de dicto es, simplemente, que el agente no tiene que dirigir su acción intencional hacia nadie en concreto.

${ }_{19}$ En uno de los experimentos más famosos (KAHEMANN y TVERSKY, 1974) se preguntaba por la profesión más probable de un hombre con esta descripción (traduzco aproximadamente): «Es muy tímido y retraído, siempre dispuesto a ayudar, pero con escaso interés en la gente, o en el mundo real. Un personalidad dócil y organizada, necesita orden y estructura, y tiene pasión por el detalle». Las respuestas sistemáticamente asignaban mayor probabilidad a «bibliotecario», cuyo estereotipo estaba representado en la descripción, que a otras profesiones mucho más abundantes, y por tanto, mucho más probables, como «granjero».

${ }_{20}$ En la jurisprudencia se admite la posibilidad de que haya delito sin que ningún menor llegue a prostituirse, pero (hasta donde sé), no sin que haya un menor involucrado. Dice la STS (Penal) 152/2008, de 8 de 
La lectura de dicto de la expresión «un menor de edad» en el Código Penal no ha de verse como una interpretación extensiva ajena a lo que dice expresamente (y por tanto vetada por su art. 4.1), porque puede formar parte del sentido propio del texto. Por ejemplo, el art. 189.1 CP precisa así lo que se considera pornografía infantil:

a) Todo material que represente de manera visual a un menor o una persona con discapacidad necesitada de especial protección participando en una conducta sexualmente explícita, real o simulada. [...]

d) Imágenes realistas de un menor participando en una conducta sexualmente explícita o imágenes realistas de los órganos sexuales de un menor, con fines principalmente sexuales.

La referencia a «un menor» en el primer inciso es ambigua, por cuanto puede designar a un menor específico (lectura de re) o a algún menor inespecífico e incluso inexistente (lectura de dicto). Pero en el otro inciso $d$ ) la referencia a «un menor» es claramente de dicto, porque al hablar de «imágenes realistas» incluye expresamente la posibilidad de que el menor no sea una persona real sino una mera imagen virtual.

\subsection{3. «Una mujer»}

Art. 144 CP: «El que produzca el aborto de una mujer, sin su consentimiento, será castigado con la pena de prisión de cuatro a ocho años e inhabilitación especial para ejercer cualquier profesión sanitaria, o para prestar servicios de toda índole en clínicas, establecimientos o consultorios ginecológicos, públicos o privados, por tiempo de tres a diez años.

Las mismas penas se impondrán al que practique el aborto habiendo obtenido la anuencia de la mujer mediante violencia, amenaza o engaño».

(33) Es delito producir el aborto de una mujer sin su consentimiento.

(33a) De dicto: producir que una mujer cualquiera (inespecífica) aborte.

(33b) De re: producir que una mujer determinada (específica) aborte.

En este supuesto ambas lecturas requieren que haya una mujer real y existente, pues el aborto ha de producirse (no basta con facilitarlo o provocarlo). Pero es ambi-

abril (FD 6. ${ }^{\circ}$ ): «Inducir, promover, favorecer y facilitar son conductas que, aun estando orientadas a la consecución de un determinado propósito, agotan su propia entidad aunque el mismo no se alcance, por lo que cabe entender que su contenido del injusto es independiente de que se produzca o no el resultado querido por el sujeto activo». En el mismo sentido, STS (Penal) 809/2006, de 18 de julio (FD 2. ${ }^{\circ}$ ), STS (Penal) 510/2010, de 21 de mayo (FD 1. ${ }^{\circ}$ ) y Auto del TS (Penal) 1317/2014, de 4 de septiembre. En la doctrina, puede verse QUERALT (2014: 280): «Lo decisivo es, pues, un eficaz influjo psicológico, que haga nacer o desarrolle el deseo de prostituirse del menor». Además, el dolo requiere que haya una víctima real: «Se trata de un delito doloso; ha de abarcar el conocimiento de la menor edad o discapacidad de la misma» (ibid., 281). Las modalidades comisivas son amplias, pero no tanto como para abstraer la víctima. Al respecto dice CUGAT (en ÁLVAREZ GARCÍA, 2010, I: 491): «Los términos en los que se describe la conducta delictiva permite incluir cualquier tipo de contribución a la prostitución del menor o incapaz». Porque «la víctima del delito es el menor o incapaz» (ibid.). Nótese: el menor. Una interpretación más extensiva del tipo la defienden MORALES PRATS y GARCÍA Albero (en QuinTERO, 2011, I: 1207): «Trata pues el Código de incriminar, indiferenciadamente, conductas que inciden, con mayor o menor intensidad, en la conformación de un mercado de prostitución de menores». Además - añaden - «el tipo se configura como infracción de mera actividad que no exige de un resultado separable o añadido a la acción de inducir, promover, favorecer o facilitar»; de modo que «no es preciso que el menor llegue materialmente a prostituirse, bastando el peligro o riesgo de que subsiga tal resultado (STS 21 mayo 2010)» (ibid., 1208). 
guo si el tipo penal exige o no que el autor trate directamente con la víctima ${ }^{21}$. La lectura de dicto calificaría dentro del tipo, por ejemplo, diseminar una sustancia abortiva en un comedor universitario para causar el aborto de alguna mujer embarazada que pudiese consumirla inadvertidamente, siempre que la acción resulte efectivamente en un aborto. En la lectura de re, en cambio, el autor ha de conocer a la mujer que aborta y actuar sobre ella. Los casos que se plantean en la jurisprudencia y en la doctrina son de esta segunda lectura ${ }^{22}$.

\subsection{4. «Una persona»}

La expresión «una persona» abunda en el Código Penal y normalmente hace clara referencia a una persona real que es víctima del delito. Muchos delitos requieren para existir que el perjuicio o la acción se concreten en una víctima específica, que la redacción legal nombra de manera genérica o inespecífica como «una persona» ${ }^{23}$. En tales casos el contexto semántico y pragmático determina que la interpretación de re de la fórmula «una persona» sea la única posible y la única admitida en la práctica por los juristas. Pero esta lectura de re tiene otras veces alternativas y en ocasiones ni siquiera es admisible. Por ejemplo, el Código Penal español emplea la expresión de dicto en el art. 127 quater, al autorizar el decomiso de efectos y ganancias transferidos a terceros «cuando una persona diligente habría tenido motivos para sospechar, en las circunstancias del caso, de su origen ilícito». Claramente, el artículo no alude a ninguna persona diligente específica pero todavía desconocida, sino a una clase de personas que incluso puede ser hipotética: el artículo es inteligible aunque no haya en el mundo ninguna persona diligente. Es decir, el Código Penal normalmente se refiere a personas reales y efectivas, pero a veces no; y puede ser un problema determinar cuál es el caso. La posibilidad de lecturas de dicto de expresiones como «una persona» en el Código Penal debe alertar a quienes preferirían adoptar una actitud de incredulidad o escepticismo hacia la ambigüedad de dicto/de re. Las lecturas de dicto son posibles y vigentes en el derecho, y en ocasiones son posibles simultáneamente (ambiguamente) con las lecturas de re.

21 En ambas interpretaciones el delito requiere una mujer real que aborta, pero en la lectura de re la mujer ya está identificada antes del aborto, mientras que en la lectura de dicto la concreción no es necesaria antes del aborto. La diferencia se ve quizás más claramente aplicando la teoría del dolo eventual. Con esta doctrina, el agente comete el delito del art. $144 \mathrm{CP}$ aunque no quiera producir el aborto de ninguna mujer: basta con que quiera los actos que llevan a ese resultado. En tal caso, «una mujer» se refiere a una persona real, pero inespecífica.

22 VAlle MuÑIZ y Quintero (en Quintero, 2004, 94) subrayan que «se prohíbe la producción de un aborto sin más especificaciones» y que el resultado «puede ser alcanzado de cualquier forma». Sin embargo, para Cugat (en Álvarez García, 2010, I, 131) esto «no significa que cualquier conducta que de algún modo contribuya al aborto, realice el tipo». En cualquier caso, ninguno plantea supuestos de dolo dirigido a una víctima abstracta.

23 El Código Penal se refiere a víctimas reales de actos o de hechos, por ejemplo, cuando habla de «la muerte de una persona» (arts. 131.3 o 133.2), el acoso a «una persona» (art. 172 ter), el atentado «contra la integridad moral de una persona» (art. 175), no socorrer a «una persona que se halle desamparada y en peligro manifiesto y grave» (art. 195), etc. El art. 510 CP es un caso especial, pues habla de incitar al odio y de otras actuaciones «contra una persona determinada», con lo cual subraya que en este delito ha de haber una víctima específica; pero suscita la pregunta de si han de recibir una interpretación distinta, a contrario sensu, los delitos donde el tipo se refiere genéricamente a «una persona» sin cualificarla como determinada. 
Así las cosas, la dificultad estriba en detectar y resolver los casos de ambigüe$\mathrm{dad}^{24}$. Por ejemplo, hay ambigüedad en la expresión «una persona con discapacidad» empleada en el art. 188.1 CP, idéntica a la examinada en la expresión «un menor de edad» que le precede; y también en el art. 189.1, también citado, al precisar lo que se considera pornografía infantil. Asimismo, cabe apreciar ambigüedad en la fórmula «alguna persona» del art. $313 \mathrm{CP}:$ «El que determinare o favoreciere la emigración de alguna persona a otro país simulando contrato o colocación, o usando de otro engaño semejante». Aunque la conducta de determinar la emigración parece requerir una persona concreta que emigre, no así la de favorecer la emigración, pues la acción puede realizarse aunque nadie emigre. Por eso el delito de favorecer la emigración de alguna persona simulando contrato o colocación admite tanto lecturas de re (según la cual ha de haber un emigrante involucrado) como de dicto (según la cual puede haber delito sin emigrantes involucrados); y la primera es la normal ${ }^{25}$.

La concordancia de los arts. 164 y $168 \mathrm{CP}$ nos ofrece otro ejemplo de ambigüedad en la expresión «una persona». El art. $164 \mathrm{CP}$ castiga «el secuestro de una persona exigiendo alguna condición para ponerla en libertad»; lo cual solo puede leerse de re, pues para que haya secuestro ha de haber una víctima real secuestrada. Pero el art. $168 \mathrm{CP}$ castiga «la provocación, la conspiración y la proposición para cometer los delitos previstos en este Capítulo», entre los cuales está «el secuestro de una persona» castigado en el art. 164 CP. Por tanto, es delito la proposición para cometer el secuestro de una persona. Lo cual puede interpretarse de dicto (proponer el secuestro de alguien, sin concretar la víctima) o de re (proponer el secuestro de alguien en particular) ${ }^{26}$.

24 Algunos supuestos de potencial ambigüedad son tan insólitos que difícilmente serían tomados en serio si se planteasen en la práctica. Son casos donde el lenguaje crea la ambigüedad pero los usos jurídicos la despejan, y se resolverían eventualmente con una reducción al absurdo. Por ejemplo el art. 456.1 CP sanciona a: «Los que, con conocimiento de su falsedad o temerario desprecio hacia la verdad, imputaren a alguna persona hechos que, de ser ciertos, constituirían infracción penal, si esta imputación se hiciera ante funcionario judicial o administrativo que tenga el deber de proceder a su averiguación». La lectura obvia y natural del artículo toma de re la expresión «alguna persona», entendiendo que hay alguien concreto víctima de la calumnia. Pero desde un punto de vista puramente lingüístico la redacción legal admite también una lectura de dicto, según la cual habría delito si se denuncia falsamente una infracción penal ante un funcionario que deba investigarla diciendo que hubo de cometerla alguna persona, pero sin especificar quién. El bien protegido ya no sería aquí el honor de nadie, sino el mismo interés público que protege el art. 457 CP (que castiga a quien denuncia una infracción legal inexistente, provocando actuaciones procesales). De hecho, la lectura de dicto del art. 456.1 CP hace redundante esa parte del art. $457 \mathrm{CP}$; lo cual es, sin duda, un argumento para rechazarla, añadido a su propia extravagancia. Pero ni la extravagancia ni la redundancia eliminan completamente la ambigüedad.

${ }^{25}$ Así, Villacampa Estiarte (en Quintero Olivares, 2014, II: 595) alude repetidamente al «sujeto pasivo del delito», dando a entender que no contempla la posibilidad de que este delito carezca de un sujeto pasivo. Es verdad que el requisito de que la conducta de favorecer la emigración se haga «simulando contrato o colocación» invita a pensar en una persona concreta contratada ficticiamente. Pero no hay razón lingüística para excluir la posibilidad de cometer el delito favoreciendo la emigración con falsas ofertas de contratación innominadas, dirigidas a potenciales emigrantes, incluso antes de que esas ofertas lleguen a atraer de hecho a nadie.

26 Quintero (en Quintero Olivares, 2011, I: 1032) relaciona este artículo con «los responsables de los actos preparatorios» de los delitos de detención ilegal y secuestro; y destaca que, a efectos de determinar la pena, «la duración del secuestro» puede ser desconocida con anticipación. Con esto da a entender que el delito consiste en haber preparado un secuestro o una detención efectivamente producidos, por tanto de una persona real. El modo en que QUINTERO se expresa excluye la posibilidad de aplicar el tipo a quien propone un secuestro en abstracto, sin víctima prefijada, pero con intención clara y plan suficiente para que se lleve a cabo. 


\subsection{Doble inespecificidad}

Una oración puede poseer ambigüedad específico/inespecífico por razones sintácticas o semánticas que se combinan o se solapan con la distinción lógica de dicto/de re. En tales casos esta distinción ayuda a interpretar la oración y a reconocer las alternativas disponibles. Veamos algún ejemplo.

\subsection{1. «El Rey»}

Los nombres de cargos y posiciones tienen una característica ambigüedad inespecífico/específico, porque puede entenderse que designan al cargo (interpretación atributiva, inespecífica) o a quien lo desempeña (interpretación individual o referencial, específica). Por ejemplo, «el rey» puede referirse a la institución («El rey puede ser menor de edad») o a la persona («El rey tiene dos hijas»). Cuando esta ambivalencia se combina con la ambigüedad de dicto/de re, el resultado es una doble ambigüedad.

Art. 490.2 CP: «Con la pena de prisión de tres a seis años será castigado el que amenazare gravemente a cualquiera de las personas mencionadas en el apartado anterior [entre ellas: $e l$ Rey], y con la pena de prisión de uno a tres años si la amenaza fuera leve».

(34) Es delito amenazar gravemente al Rey.

$\left(34 a_{1}\right)$ De dicto atributiva: amenazar a la Casa Real.

$\left(34 a_{2}\right)$ De dicto individual: amenazar a la persona que sea rey (ahora o en el futuro)

$\left(34 b_{1}\right)$ De re atributiva: amenazar a la persona que es rey por serlo.

$\left(34 b_{2}\right)$ De re individual: amenazar a la persona que es rey sin tener en cuenta que lo es.

En la lectura de dicto el sustantivo «Rey» no se refiere a ninguna persona concreta. En la versión atributiva no se refiere a ninguna persona, sino a la institución. Se castigaría a quien amenazase de muerte a la «Casa Real» o a la «Monarquía»; y en general a la institución real como tal institución ${ }^{27}$. En la versión de dicto individual, «rey» refiere a una persona posible; y sería delito, digamos, amenazar con matar dentro de veinte años a quien sea entonces rey, si alguien lo es. La lectura de re, que invoca una persona física y actual con título de rey, también tiene dos interpretaciones. En la atributiva solo sería delito amenazar a quien se sabe que es rey y porque lo es. En la versión individual sería delito amenazar de muerte a un motorista con casco que resulta ser el rey. La lectura de re atributiva es la más próxima a los juristas, pero no la única posible ${ }^{28}$.

27 Esta interpretación es extraña, pero sorprendentemente posible. Al parecer (no he podido localizar la sentencia), la Audiencia Nacional condenó el 17 de marzo de 2015, tras un acuerdo de conformidad, a una persona que escribió en Twitter (junto a otras amenazas): «Algún día asesinaré a la Casa Real» (noticia publicada el 18 de marzo de 2015 por Europa Press: http://www.europapress.es/nacional/noticia-condenadospagar-380-desear-muerte-rey-twitter-20150318133658. btml. Enlace comprobado el 21 de julio de 2016). Con todo, una interpretación así fuerza el significado de «Rey» y choca con el tenor del art. 490.2 CP, que habla de amenazar a «las personas». Para castigar las amenazas a instituciones la redacción debería ser otra, en el estilo del art. 504.1 CP, se refiere a «los que calumnien, injurien o amenacen gravemente al Gobierno de la Nación, al Consejo General del Poder Judicial, al Tribunal Constitucional», etc. Estas son fórmulas que designan las instituciones y no sus miembros.

28 Téngase en cuenta que el apartado 3 del mismo art. $490 \mathrm{CP}$ castiga al que «calumniare o injuriare al Rey [...] en el ejercicio de sus funciones o con motivo u ocasión de estas», con lo cual sugiere a contrario que el apartado 2 no requiere que la amenaza se dirija al rey en ejercicio de sus funciones. TAMARIT SUMALLA y Rodríguez Puerta (en Quintero Olivares, 2011, II: 1470) consideran — con Córdoba Roda- que 


\subsection{2. «Otro»}

Muchos artículos del Código Penal utilizan la palabra «otro» en su acepción pronominal, para referir a una persona indeterminada pero específica. Así, se castiga al que «matare a otro» (art. 138), «causare a otro una lesión» (art. 147), «encerrare o detuviere a otro» (art. 164), etc. En estos casos no hay ninguna ambigüedad, porque la lectura de re es la única posible. Esos artículos tratan sobre personas reales víctimas del delito. Pero a veces la redacción legal suscita la duda de si el artículo se refiere a una persona concreta y real o a una persona en abstracto $^{29}$. Es el caso del art. $248.1 \mathrm{CP}$ que abre este trabajo.

Art. 248.1 CP: «Cometen estafa los que, con ánimo de lucro, utilizaren engaño bastante para producir error en otro, induciéndolo a realizar un acto de disposición en perjuicio propio o ajeno».

Es delito utilizar engaño bastante para producir error en otro induciéndole...

En la lectura inespecífica (35a) sería delito crear una apariencia de empresa eficaz para captar dinero ajeno sin dar contraprestación alguna, aunque nadie llegue a caer en el engaño. En la lectura específica $(35$ b), por supuesto la habitual, no hay estafa sin una víctima concreta ${ }^{30}$. Esta ambigüedad entre versiones inespecíficas y específicas de «otro» es análoga a la ambigüedad de dicto/de re que veíamos en «una persona»; y de hecho en la mayoría de los casos «otro» podría sustituirse por «una persona» con resultado jurídicamente idéntico (son expresiones correferentes y tienen la misma intensión).

«debe exigirse que la amenaza llegue a conocimiento del sujeto pasivo». Esta condición es incompatible con la interpretación de dicto que incluye en el tipo la amenaza a un eventual rey futuro. Personalmente creo que es una condición sensata, pero, no obstante, la lectura de dicto cabe en la letra del artículo. También es sensato exigir que el autor conozca la identidad real (valga el juego de palabras) de la persona amenazada. En su comentario del supuesto análogo contenido en el art. 485.1 CP («El que matare al Rey...»), dicen Tamarit Sumalla y Rodríguez Puerta (en Quintero Olivares, 2011, II: 1466): «El dolo debe abarcar el conocimiento de la identidad y la condición de las personas especialmente protegidas». Por tanto, se prefiere (con exclusión de otras) la lectura de re inespecífica, donde la víctima del delito es una persona concreta (existente), pero no la persona por sí misma (como individuo específico), sino por su estatus (como titular de una institución).

${ }^{29}$ Incluso las leyes penales claramente orientadas de re pueden tener lecturas de dicto en caso de tentativa. El delito de «matar a otro» exige sin duda una víctima, pero la tentativa de matar a «otro» podría ser punible aunque no vaya contra nadie en particular o nadie estuviese realmente en peligro de muerte (por ejemplo, si un individuo entra en un colegio con un fusil, abre la puerta de un aula y dispara repetidamente, pero no hay nadie dentro).

${ }^{30}$ Dicen Valle MuÑIZ y Quintero (en Quintero, 2004, 631): «Si algo caracteriza al delito de estafa con respecto al resto de delitos de enriquecimiento es la necesidad, en el iter comisivo, de la cooperación del sujeto víctima del engaño, lo que se formaliza a través del requisito del acto de disposición». La interpretación ortodoxa no ve delito cuando hay una víctima potencial, pero no actual. Dice QUINTERO (en QUINTERO, 2011, II: 81): «El engaño es idóneo si realmente ha producido un error»; y «culmina con el acto de disposición, que por ser algo que realiza el "engañado" exige la identidad personal entre disponente y engañado». Por otra parte, no hay estafa sin daño real, no basta con crear un riesgo por grave que sea: «La estafa es un delito de resultado material que exige la lesión del bien jurídico protegido que es el patrimonio ajeno, en el que ha de provocar una mengua» (ibid., 82). Crear un riesgo sería a lo sumo tentativa: «La tentativa solo cabría en casos de engaño idóneo pero en los que la víctima no llega a realizar el acto de disposición por causas sobrevenidas» (ibid.). 
Como se apuntó en la Introducción, la palabra «otro» se usa en español para referirse a personas concretas («Pedro acusó a otro») o abstractas («Pedro fingió ser otro»); y a veces de modo ambiguo («Pedro se hizo pasar por otro»). No hay ambigüedad cuando la información contextual o semántica la despeja, y esto ocurre a menudo. Por ejemplo, el art. $401 \mathrm{CP}$ dice: «El que usurpare el estado civil de otro será castigado con la pena de prisión de seis meses a tres años». Simular el estado civil de «otro» puede entenderse de re, referido a una persona concreta y real a la que se suplanta; o de dicto, referido a una identidad distinta del sujeto, aunque sea ficticia. Pero el artículo no habla de «simular» ni de «adoptar», sino de «usurpar», y la semántica de este verbo exige una víctima concreta y real (no se puede «usurpar» una identidad ficticia). Si el legislador quiere evitar la ambigüedad cuando la detecta en el proceso de redacción legislativa, hará bien introducir marcadores semánticos como este para dirigir la interpretación en un solo sentido.

Un problema especialmente difícil en el tema que tratamos es interpretar el castigo de la inducción del delito. El art. $28 \mathrm{CP}$ considera autores del delito a «los que inducen directamente a otro u otros a ejecutarlo». En teoría, «otro» puede leerse de dicto, según lo cual es autor quien induce a cometer delitos aunque nadie en concreto sea inducido. Sin embargo la tesis doctrinal más extendida es que la inducción penada en el art. 28 $\mathrm{CP}$ requiere que el hecho delictivo que se induce se cometa efectivamente, lo cual implica naturalmente que el sujeto inducido ha de ser una persona real y existente y no una mera posibilidad teórica. Pero esta doctrina es frágil y sus implicaciones no son del todo claras. Por ejemplo, no está claro cómo afecta al delito de inducción al suicidio (art. $143 \mathrm{CP}$ ) o al de inducción de menores a la prostitución (art. 188.1 CP); porque la doctrina da respuestas diferentes a cada caso. «El que induzca al suicidio de otro será castigado con la pena de prisión de cuatro a ocho años», dice el art. 143.1 CP. En teoría este tipo penal podría entenderse como un delito de actividad (la inducción) que no requiere la producción efectiva del resultado buscado (el suicidio); en cuyo caso por «otro» cabría entender no solo una persona actual a quien el autor insta a suicidarse (lectura de re), sino también un suicida potencial cualquiera, que podría no llegar a existir o ser desconocido para el autor. Pero esta interpretación teórica es inviable por cuanto la jurisprudencia y la doctrina condicionan el castigo penal de la inducción a que sea exitosa. Ha de haber un suicida, y el «otro» que menciona el artículo es ese suicida, por tanto una persona real y no una mera posibilidad ${ }^{31}$. De esta manera, la potencial ambigüedad de la palabra «otro» en el art. 143.1 CP, donde puede referirse a alguien concreto e identificado o a alguien abstracto y meramente posible, se despeja de derecho, porque no hay inducción al delito sin delito, ni inducción al suicidio sin suicida $^{32}$. En cambio, como ya vimos, no ocurre lo mismo al interpretar el art. 188.1 CP

31 Como indica Quintero en su comentario del art. 143 CP (en Quintero Olivares, 2011, I: 899): «La interpretación de lo que ha de entenderse por inducción se ha hecho siempre en sintonía con la interpretación que a su vez se dé a la inducción al delito; [...], incluyendo, lógicamente, la necesidad de que el suicidio se produzca». En este sentido, el propio QUINTERO al comentar el art. 28 CP (ibid., I: 342) explica que «de acuerdo con larga tradición jurisprudencial y doctrinal, la inducción ha de ser a persona determinada, a delito concreto y ha de ser eficaz» (cursivas en el original).

32 Esta misma argumentación es aplicable al sintagma «una persona» del art. 143.3 CP: «Se impondrá la pena de prisión de dos a cinco años al que coopere con actos necesarios al suicidio de una persona». En una primera impresión cabría apreciar aquí la ambigüedad de dicto/de re. Leído de dicto castiga cooperar para que alguna persona pueda eventualmente suicidarse (por ejemplo publicando cómo conseguir y utilizar un produc- 
(«El que induzca, promueva, favorezca o facilite la prostitución de un menor de edad o una persona con discapacidad necesitada de especial protección...»). En este caso la jurisprudencia aclara que para que haya delito no es necesario que ningún menor se prostituya (vid. nota 17 supra). Por tanto, la tensión de dicto/de re al interpretar la inducción del delito es un problema que no está del todo resuelto. La solución puede consistir en diferenciar entre la inducción general del art. 28 CP y la inducción especial de los arts. 143.1 o $188.1 \mathrm{CP}$, o en diferenciar entre inducción y provocación ${ }^{33}$; pero las preguntas siguen abiertas. Por ejemplo, ¿cómo interpretar el art. $224 \mathrm{CP}$, que castiga a «el que indujere a un menor de edad o a una persona con discapacidad necesitada de especial protección a que abandone el domicilio familiar»?

\subsection{Retos interpretativos}

La ambigüedad de dicto/de re es un fenómeno lógico y lingüístico que merece atención por los juristas y que puede pasar fácilmente desapercibido. La inclinación de los juristas por la lectura de re cuando el texto la permite se explica seguramente por los heurísticos que el cerebro emplea para procesar la información, los cuales determinan sesgos cognitivos bien documentados. Pero todo esto pertenece al contexto de descubrimiento, y al jurista le interesa no solo conocer y entender cómo y por qué razona como lo hace, sino también —y quizá sobre todo— justificar sus razonamientos. La pregunta clave, entonces, es qué interpretación está justificada, o tiene mejor justificación, en los casos de ambigüedad.

No sostengo que los juristas se equivoquen al adoptar únicamente las versiones de $r e$ en los enunciados legales ambiguos. Sí sostengo que se equivocan cuando no tienen en cuenta otras posibilidades, cuando no piensan en ellas, aunque sea para rechazarlas. Muchos casos de ambigüedad de dicto/de re tendrán una solución jurídica clara, sea cual sea la doctrina interpretativa que sigamos. La intención del legislador, los fines objetivos de la norma y el significado público del texto son los tres intereses fundamentales de la interpretación jurídica; y aunque pueden ser antagónicos, a menudo confluirán en la misma respuesta, probablemente la versión de re por cuanto el redactor del texto y sus destinatarios comparten los mismos sesgos cognitivos. Pero habrá casos de divergencia entre los enfoques interpretativos; casos, por ejemplo, donde cualquiera que preste atención puede percibir y dar sentido a la lectura de dicto, pero una tesis finalista o la indagación intencionalista la descartan. En mi opinión, en estos casos no estaría justificado prescindir de la lectura de dicto sin ulteriores argumentos.

En los asuntos penales, por ejemplo, podrían invocarse tres argumentos importantes para inclinar la balanza interpretativa. El primero es el requisito de dolo, que podría exigir alguna figuración y conocimiento de la víctima (por ejemplo, de su edad o de su embarazo). Pero la exigencia de dolo ha de desprenderse de la lectura del Código

to letal e indoloro «idóneo para suicidarse»). Leído de re, en cambio, castiga cooperar para que una persona concreta llegue a suicidarse. Pero esta teórica ambigüedad de «una persona» en el art. $143.3 \mathrm{CP}$ se despeja igual que la de «otro» en el apartado 1, porque se entiende unívocamente que para que haya cooperación necesaria al suicidio ha de haber suicidio, y, por tanto, un suicida real y no meramente hipotético.

33 Al respecto, Quintero Olivares, 2011, I: 342. 
Penal y no esta de aquella; y por otra parte el dolo puede consistir en la intención de causar el daño descrito de dicto en el artículo (por ejemplo, provocar abortos a mujeres desconocidas). Un segundo argumento es que la seguridad jurídica y el principio de legalidad penal imponen respetar las expectativas, porque si siempre se ha entendido un artículo únicamente de re, podría ser arbitrario aplicarlo de dicto sin previo aviso. Pero, previo aviso, la posibilidad de ampliar la interpretación para el futuro está abierta. Alguien podría discrepar y sostener que ampliar la interpretación del Código Penal con lecturas de dicto en las que nadie había reparado es una forma de interpretación extensiva que contraviene la legalidad penal estricta. La objeción no es menor, pero a mi juicio no hay interpretación extensiva cuando no se abandona el significado del texto tal como cualquier hablante competente puede entenderlo, aunque sea en una segunda lectura más atenta. El tercer argumento es el principio In dubio pro reo, cuya fuerza se dirige sobre todo a la valoración de la prueba, pero que también se proyecta sobre la interpretación como un canon hermenéutico. Aplicando este principio, si un artículo es ambiguo y no está claro si todas las opciones son viables a la vez o, de no serlo, cuáles son inadmisibles, cabría defender que debe optarse por la interpretación más favorable al reo, que normalmente será la lectura de re. Pero este principio - circunscrito en todo caso al ámbito penal - no prevalece frente a otras razones interpretativas más poderosas, como la obligación de guiarse por la Constitución y sus valores, los cuales pueden justificar en algún caso la penalidad de conductas que el Código Penal solo nombra de dicto.

\section{BIBLIOGRAFÍA}

ABelardo, ed. 1958: «Glosse Super Periermenias, capp. XII-XIV», en L. Minio-Paluello, Twelfth Century Logic. Texts and Studies. II. Abaelardiana Inedita: 1. Super Periermenenias XII-XIV. 2. Sententie Secudum M. Petrum, Roma: Edizione di Storia e Letteratura, 13-14.

Álvarez García (dir.), 2010: Derecho penal español. Parte especial, vols. I y II, Valencia: Tirant lo Blanch.

ANDERSON, 2014: «Misreading Like a Lawyer. Cognitive Bias in Statutory Interpretation», Harvard Law Review, 127: 6, 1521-1592.

Aristóteles, ed. 1982: Tratados de Lógica, trad. de M. Candel SANMARtín, Madrid: Gredos.

FREGE, 1892/2005: «Über Sinn und Bedeutung», Zeitschrift für Philosophie und philosophische Kritik, 100, 25-50. Se cita por la trad. esp. de U. MouLINES: «Sobre sentido y referencia», repr. en L. M. ValdÉs VilLanUeva (ed.), La búsqueda del significado, Madrid: Tecnos, 2005 (4. ${ }^{a}$ ed.), 29-49.

GARCíA SUÁREZ, 1997: Modos de significar. Una introducción temática a la filosofía del lenguaje, Madrid: Tecnos (hay 2. ${ }^{a}$ ed. 2011).

GUTIÉRREZ ORDÓÑEZ, 1995: «Referencia y pronominalización "de dicto"», LEA (Lingüistica española actual), 17: 1, 49-68.

ITURRALDE, 2011: Interpretación literal y significado convencional. Una reflexión sobre los límites de la interpretación jurídica, Madrid: Marcial Pons.

KAHNEMAN y TVERSKY, 1974: «Judgement under Uncertainty: Heuristics and Biases», Science, 185, núm. 4157, 1124-1131. Hay trad. esp. de J. CHAMORRO: «El juicio bajo incertidumbre: Heurísticas y sesgos», en D. Kahneman, Pensar rápido, pensar despacio, Madrid: Debate, 2012 (apéndice). 
KELSEN, 1960-1991: Reine Rechtslehre, Viena: Franz Deuticke, 1960 (2. ${ }^{\text {a ed. }}$.). Se cita por la trad. esp. de R. Vernengo: Teoría Pura del Derecho, México: Porrúa-UNAM, 1991.

KNeale, 1960: «Modality De Dicto and De Re», en E. NAgel, P. SuppeS y A. TARSKI, Logic, Methodology and Philosophy of Science, Stanford: Stanford University Press, 622-633.

LAmarque (ed.), 1997: Concise Encyclopedia of Philosophy of Language, Oxford: Pergamon.

PINZANI, 2003: The Logical Grammar of Abelard, Dordrecht: Kluwer.

Queralt Jiménez, 2015: Derecho penal español. Parte especial, 7. a ed., Valencia: Tirant lo Blanch. QuiNe, 1956: «Quantifiers and Propositional Attitudes», Journal of Philosophy, 53: 5, 177-187. Hay trad. esp. de L. M. VALDÉS: «Cuantificadores y actitudes proposicionales», en L. M. ValdÉs Villanueva (comp.), La búsqueda del significado, Madrid: Tecnos, 1999 (4. a ed.), 171-182.

- 1960: Word and Object, Cambridge (Mass.): MIT Press, 1960. Hay trad. esp. de M. SACRISTÁN: Palabra y objeto, Barcelona: Labor, 1968.

- 1961: From a Logical Point of View, 2. ${ }^{a}$ ed., Cambridge (Mass.): Harvard University Press (1. a ed. 1953). Se cita por la reimpr. de New York: Harper \& Row, 1963. Hay trad. esp. de M. SACRISTÁn: Desde un punto de vista lógico, Barcelona: Ariel, 1962; reed. en Barcelona: Paidós, 2002.

Quintero Olivares (dir.), 2004: Comentarios a la Parte Especial del Derecho Penal, Madrid: Thomson-Aranzadi.

- 2011: Comentarios al Código Penal Español, 2 vols., Madrid: Aranzadi/Thomson Reuters, 6. ${ }^{a}$ ed. (primera con este título).

LEIBNIZ, ed. 1890: «Specimen Calculi universalis», en Die philosophische Schriften (ed. C. I. GERHARDT), vol. VII, Berlin: Weidmann.

ReAl ACADEMIa Española, 2009: Nueva gramática de la lengua española, 2 vols. (I: Morfología. Sintaxis I; II: Sintaxis II), Madrid: Real Academia Española y Asociación de Academias de la Lengua Española/Espasa.

RuSSELL, 1905: «On Denoting», Mind, 14: 56, 489-493.

Whitehead y Russell, 1927: Principia Mathematica, 2. ${ }^{a}$ ed., vol. I, Cambridge: Cambridge University Press (1. ${ }^{\text {a }}$ ed. 1910); reimpr. de 1963.

YAfFe, 2011: «De Dicto and De Re Intention in Attempted Crimes», en A. Marmor y S. SoAMES (eds.), Oxford: Oxford University Press, 184-216. 